\title{
„Europejska konferencja edukacji informacyjnej” (Tallinn, Estonia, 19-22 października 2015 r.)
}

W dniach 19-22 października 2015 r. w Tallinie odbyła się 3. edycja „European Conference on Information Literacy" (ECIL), zorganizowana przez Katedrę Nauk o Informacji Szkoły Technik Cyfrowych Uniwersytetu w Tallinie, Wydział Nauk o Informacji i Komunikacji Uniwersytetu w Zagrzebiu oraz Wydział Zarządzania Informacją Uniwersytetu Hacettepe w Ankarze.

W konferencji uczestniczyło 361 osób z 50 krajów. ECIL, to, obok angielskiego LILAC, największe i najważniejsze coroczne spotkanie bibliotekarzy i badaczy zajmujących się kompetencjami informacyjnymi i edukacją informacyjną, odbywające się w Europie. Podczas czterodniowych obrad odbyło się 10 warsztatów, wygłoszono 129 referatów (w sesjach równoległych), 18 krótkich prezentacji (tzw. pecha-kucha), zaprezentowano 19 posterów, sześć prezentacji z badań doktoranckich, odbyła się jedna dyskusja panelowa.

Wybrane referaty zostały opublikowane w recenzowanym tomie pokonferencyjnym, nakładem wydawnictwa Springer w ramach serii Communications in Computer and Information Science (Kurbanoglu et al., eds. 2015).

Referaty w sesjach zostały podzielone na 23 bloki tematyczne:

- Approaches to information literacy,

- Copyright literacy,

- Development and evaluation of information literacy,

- Digital literacy,

- E-learning and m-learning,

- Everyday life media and information literacy,

- Health information literacy,

- Information and digital literacy instruction,

- Information literacy - government and society,

- Information literacy and academic libraries,

- Information literacy and information culture in higher education,

- Information literacy and learning,

- Information literacy and sustainability,

- Information literacy and technology,

- Information literacy instruction,

- Innovative information literacy approaches,

- Media and visual literacy,

- Policy and strategy,

- Professional development and information literacy,

- Professional information literacy,

- Reading format preferences of students - print vs electronic,

- Social networking and gaming,

- Standards and professional practice.

W sprawozdaniu omówione zostały jedynie wybrane referaty. Szczegółowy program konferencji oraz abstrakty dostępne są na stronie ECIL 2015, http://ecil2015.ilconf.org/.

Organizatorzy zaprosili jako główne referentki: Sonię Livingstone, Susan Danby oraz Carol Collier Kuhlthau. 
Sonia Livingstone z Uniwersytetu Londyńskiego wygłosiła referat podczas sesji otwierającej. Nawiązała w nim do badań realizowanych w ramach sieci EU Kids Online, w latach 2006-2014. Szczególnie interesujące były przytoczone przez Livingstone wyniki badań jakościowych (obserwacji rodzin), których celem było poznanie sposobu postrzegania przez rodziców zachowań i kompetencji medialnych ich dzieci. Badania pokazały, że rodzice koncentrują się przede wszystkim na kompetencjach technicznych, np. sposobie obsługi urządzeń. Mniej uwagi poświęcają kompetencjom krytycznym, które wiążą się z rozumieniem przez dzieci, czym jest Internet, kto udostępnia w nim treści i w jakim celu. Komponent jakościowy w EU Kids Online rzucał nowe światło na wyniki badań ilościowych, np. niskich kompetencji krytycznych w odniesieniu do korzystania z mediów. Livingstone akcentowała również znaczenie wielowymiarowej analizy danych, która pozwalała interpretować zgromadzone dane na różnych poziomach: (1) jednostkowym, (2) społecznym (np. rodziny) i (3) kraju. Jest to szczególnie istotne, jeżeli badania mają być podstawą do budowania polityki informacyjnej, w tym polityki dla edukacji medialnej i informacyjnej opartej na dowodach, i uwzględniającej lokalne potrzeby.

Wystąpienie Susan Danby z Politechniki Queensland również odnosiło się do dzieci. Danby badała zachowania medialne małych dzieci (5-7 lat) w przedszkolu i w ich środowisku domowym. Sprawdzała również jaki jest stosunek nauczycieli przedszkolnych do wykorzystania mediów w pracy z dziećmi. Stosowała metodę etnograficzną, która umożliwiła interpretacje i rozumienie sytuacji uczenia się różnych narzędzi cyfrowych przez bardzo młodych użytkowników, np. korzystania z map Google przez dzieci niepotrafiące jeszcze czytać. Zwracała uwagę na interakcje dzieci-komputer i dzieci-dorośli. Badania były realizowane w Australii. Kultura tego kraju - w szczególności czynniki demograficzne (np.gęstość zaludnienia) czy podejście do technologii mieszkańców obszarów rolniczych - stanowi istotny kontekst do rozumienia wyników badań.

Carol Collier Kuhlthau, emerytowana profesor Uniwersytetu Rutgersa, zaprezentowała podejście do uczenia się określane jako dociekanie ukierunkowane lub ukierunkowane dociekanie naukowe (ang. guided inquiry). Charakterystyczną cechą tego podejścia jest wyszukiwanie i wykorzystywanie różnych źródeł informacji, w celu rozwijania wiedzy o danym problemie, zagadnieniu. Wymaga to od uczącego zaangażowania. Proces uczenia się następuje poprzez budowanie pytań, eksplorowanie źródeł, badanie i konstruowanie odpowiedzi (wiedzy) w oparciu o znalezione informacje. Uczący się otrzymuje wsparcie od nauczycieli i bibliotekarzy, jednocześnie musi wykazać się dużą samodzielnością. To podejście przygotowuje osobę do rozwiązywania problemów (związanych z życiem codziennym, pracą) z wykorzystaniem nowoczesnych technologii. Kuhlthau poświęciła wiele uwagi w wystąpieniu modelowi Procesu Wyszukiwania Informacji (ang. Information Search Process [IPS]). Jest to model teoretyczny, przedstawiający proces wyszukiwania na trzech poziomach: fizycznym (działania), kognitywnym (myśli) i afektywnym (uczucia). Pokazuje, że wyszukiwanie to nie tylko czynności, które wykonuje użytkownik, ale także różnego rodzaju odczucia i przemyślenia, np. poczucie zagubienia, frustracja, optymizm, satysfakcja.

Sesje plenarne i równoległe były podporządkowane określonym obszarom badań/praktyki information literacy. Autorki, z uwagi na własne zainteresowania, uczestniczyły głównie w sesjach prezentujących obszar nauki i szkolnictwa wyższego. W dalszej części tekstu przedstawione zostały refleksje nad wybranymi wystąpieniami. Opisane zostały również referaty autorek zaprezentowane podczas ECIL.

Wiele wystąpień dotyczyło wsparcia przez biblioteki pracowników naukowych uczelni. Szeroko rozumiana edukacja informacyjna, skierowana na doskonalenie procesu przygotowywania do publikacji wyników badań ma pomóc w zwiększeniu liczby publikacji danej uczelni w prestiżowych czasopismach (tj. czasopismach indeksowanych w uznanych bazach). W tym kontekście Ivanka Yankova, Rumelina Vasileva, Tzvetelina Dimitrova, Kamelia Nusheva z Uniwersytetu Bibliotekoznawstwa i Technologii Informacyjnych w Sofii przedstawiły założenia programu szkoleń skierowanych zarówno do autorów jak i wydawców. Natomiast Hana Janečková i Petra Dědičová z Politechniki w Brnie zaprezentowały kurs e-learningowy skierowany do doktorantów i pracowników naukowych Publikowanie naukowe od A do Z. 
Susanne Mikki i Marta Zygmuntowska z Uniwersytetu w Bergen przedstawiły wyniki badań dotyczących obecności naukowców z ich uniwersytetu w serwisach przeznaczonych do współpracy naukowej, takich jak: ResearchGate, Akademia.edu, czy Gogle Scholar. Te badania pomogły m.in. zdefiniować najpopularniejsze serwisy, które można by polecać doktorantom (młodym naukowcom) do podnoszenia swojej rozpoznawalności na forum międzynarodowym.

Zuza Wiorogórska wygłosiła referat podsumowujący wyniki pilotażowych badań porównawczych przeprowadzonych wśród doktorantów psychologii Uniwersytetu Warszawskiego i Uniwersytetu Lille 3, dotyczących potrzeb i zachowań informacyjnych tej grupy młodych naukowców. Wyniki badań nie wykazały szczególnych różnic między użytkownikami informacji z Polski i Francji. W obu krajach respondenci zwracali uwagę na potrzebę specjalistycznej edukacji informacyjnej w ich dziedzinie nauki, takiej, która pozwoliłaby na poszerzenie umiejętności informacyjnych i - co podkreślano w obu krajach - zaoszczędzenie czasu podczas wyszukiwania literatury przedmiotu. Problemami wskazywanymi przez respondentów były: wysokie ceny najnowszych wydań psychologicznych e-czasopism, ograniczony dostęp (np. swobodny dostęp dopiero po upłynięciu okresu embarga) do wielu tytułów lub jego brak, wreszcie wysokie ceny, jakie trzeba zapłacić w przypadku indywidualnego zakupu poszczególnych artykułów. Podkreślano wartości płynące z dzielenia się wiedzą i wspólnego działania (ang. Community of Practice) - zarówno w świecie realnym (konferencje, współpraca krajowa i zagraniczna) jak i wirtualnym (media społecznościowe). Respondenci w obu krajach dostrzegli wartości, jakie niesie za sobą publikowanie w otwartym dostępie (ang. Open Access), ale albo uważali to za zbyt drogą (i dla młodych naukowców nieosiągalną) drogę publikacji wyników swoich badań, albo pragmatycznie orzekali, ze najważniejsze czasopisma (zatem te posiadające obliczony wskaźnik Impact Factor) nie są wydawane w otwartym dostępie, a tylko publikacje w takich czasopismach dają gwarancję szybkiego rozwoju kariery naukowej.

Ewa A. Rozkosz przedstawiła wyniki badań nad usytuowanym uczeniem się kompetencji informacyjnych przez małą społeczność badaczy pedagogiki krytycznej. Celem było poznanie, zrozumienie i opisanie sposobów uczenia się przez jej członków kompetencji informacyjnych. Jako ramę teoretyczną wykorzystała teorię usytuowanego uczenia się Leave i Wengera, z którą wiąże się pojęcie wspólnoty praktyk (ang. Community of Practice). Uczenie się kompetencji rozumiane było jako angażowanie się we wspólnotę praktyk informacyjnych, poprzez: (1) odtwarzanie zastanych praktyk, polegające na przesuwaniu się uczestników wspólnoty z jej obrzeży do centrum, w wyniku poznawania przez nich znaczeń, reguł i działań właściwych dla wspólnoty, (2) ich transformację, będącą następstwem napięć i negocjacji nowych znaczeń dla działań podejmowanych przez wspólnotę. Społeczność wypracowała podzielane przez członków znaczenia dla różnych sposobów korzystania z informacji. Osoby włączające się do społeczności nabywały zastane wzory i reguły (zachowań informacyjnych). Doświadczenia biograficzne członków społeczności, w tym naukowe wyjazdy zagraniczne, jak również współpraca z organizacjami pozarządowymi przy realizacji projektów naukowych, wpływały na zmianę znaczeń nadawanych określonym działaniom (zachowaniom informacyjnym) i były punktem wyjścia do ich zmiany. Jednocześnie społeczność mogła być hamulcem zmian (transformacji zachowań informacyjnych), jeżeli propozycje zmian nie uzyskiwały aprobaty członków zajmujących wyższą pozycję w hierarchii tej społeczności.

Bez względu na obszar, w którym uczestnik konferencji sytuuje siebie (jako badacza kompetencji informacyjnych lub ich edukatora), z pewnością jego uwagę przyciągnąć powinny toczące się podczas ECIL dyskusje nad pojęciem information literacy. I tak wspomniana wcześniej Carol Collie Kuhlthau zdefiniowała information literacy jako umiejętność zastosowania informacji do tworzenia wiedzy potrzebnej do mądrych działań (oryg. ability to use information to construct knowledge for wise action). Z kolei Heidi Julien określiła je jako zestaw umiejętności, wiedzy i postaw wymaganych, aby efektywnie, sprawnie i w etyczny sposób uzyskiwać dostęp do informacji (oryg. set of skills, knowledge and attitudes required to access information effectively, efficiently and ethically). W różnych definicjach akcentowano odmienne wymiary kompetencji informacyjnych: krytyczny (np.zdolność do 
refleksji nad ochroną swojego wizerunku w mediach), technologiczny (np. umiejętność korzystania z narzędzi do zarządzania informacją), ekologiczny (np.rozumienie zjawiska przeciążenia informacją) $\mathrm{i}$ inne. Zwracano uwagę na związek definicji pojęcia z kontekstem, w jakim ono się pojawia. Inaczej rozumiane są kompetencje informacyjne w badaniach efektów edukacji informacyjnej akademickiej czy szkolnej oraz w badaniach nad uczeniem się kompetencji informacyjnych w miejscu pracy. Warto odnotować, że w referatach poświęconych działaniom podejmowanym przez biblioteki w obszarze edukacji informacyjnej, kompetencje informacyjne były często utożsamiane z umiejętnością korzystania z różnych źródeł informacji oferowanych przez te instytucje. Dyskusje nad pojęciem information literacy toczące się podczas ECIL nie służyły więc wypracowaniu ujednoliconej definicji, ale podkreślaniu różnorodności podejść badawczych, kontekstów, stanowisk oraz praktyki. To podejście może inspirować do konstruowania nowych pytań badawczych i wykorzystywania nowych perspektyw w badaniach fenomenu information literacy.

Zagadnienia poruszane na konferencjach ECIL odzwierciedlają najnowsze tendencje w badaniach kompetencji informacyjnych oraz edukacji informacyjnej i ich zastosowaniu w praktyce. Na gruncie nauki i szkolnictwa wyższego warto zwrócić uwagę na to, że coraz więcej mówi się o edukacji informacyjnej dla doktorantów i pracowników uczelni, najczęściej w kontekście pomocy w przygotowywaniu publikacji naukowych, głównie tych przeznaczonych do obiegu międzynarodowego. Coraz częściej przedmiotem pogłębionej refleksji są zagadnienia węższe niż ogół kompetencji informacyjnych, np. podstawowa umiejętności związane z prawem autorskim (ang. copyright literacy) lub wykorzystywaniem surowych danych badawczych (ang. data literacy). Ponadto - edukacja informacyjna prezentowana jest jako swojego rodzaju promocja biblioteki i jej zbiorów. Im lepiej wyszkoleni użytkownicy, tym pełniej i chętniej będą korzystać z zasobów informacji oferowanych przez uczelnię.

Polskę na ECIL 2015 reprezentowały Ewa Rozkosz (DSW) i Zuza Wiorogórska (UW).

ECIL 2016 odbędzie się w dniach 10-13 października 2016 r. w Pradze.

\section{Bibliografia}

Kurbanoglu, S.; Boustany, J.; Spiranec, S.; Grassian, E.; Mizrachi, D.; Roy, L., eds. (2015). Information Literacy: Moving Toward Sustainability. Cham: Springer International Publishing.

Zuza Wiorogórska

Biblioteka Uniwersytecka $w$ Warszawie

Ewa A. Rozkosz

Dolnośląska Szkoła Wyższa

Nadestano: 2 marca 2016. 